Шевчик Б. М., bmshevchyk@gmail.com,ORCID ID: 0000-0002-0004-325X, д.е.н., проф., професор кафедри економіки, Львівський торговельно-економічний університет, м. Львів

\title{
КУЛЬТУРА, ІННОВАЦЇ̈ І ПРИБУТОК У СТАТИЧНІЙ ТА ДИНАМІЧНІЙ МОДЕЛЯХ ЕКОНОМІЧНОЇ ЕФЕКТИВНОСТІ
}

\begin{abstract}
Анотація. Розглядаються особливості функціонування економічних систем з позицій їх статичної та динамічної ефективності. 3'ясовується вплив панівної чуттєвої культури Заходу - нігілізму - на способи забезпечення прибутковості від економічної діяльності, зокрема через техногенез. Обтрунтовується неможливість вивести ідею розвитку з когнітивного патерна нормативного стандарту статичної ефективності - ринкового гомеостазу. Ринок трактується як інформаційний механізм забезпечення інсайдерства нових комбінацій у режимі динамічної ефективності як єдиної умови прибутковості фірми. Прибуток трактується як дохід за виробництво інформації - міри знятої невизначеності упорядкованого буття, даного у пізнання через проявлення якісних властивостей до того не існуючих речей. Стверджується організаційний статус альфа-патерна шумпетерівського новатора у структурі тріалектичної патернальної конфігурачї мікрорівня базових патернальних бізнес-тріад. Функиію бета-патерна виконує венчурний капіталіст, а гомеостатичного гама-патерна - маркетолог, який персоніфікує мету системи - розподіл і привласнення доходів від реалізації продукції на ринку. Інсайдерство нових комбінацій інновачійних впроваджень запускає кумулятивні кола зростаючої прибутковості в режимі дифузї інновацій. Принции розподілу тісно пов'язаний із ментальністю впроваджувачів: максимальний прибуток отримують впроваджувачі 1-2-го рівнів; конкурентна боротьба на ринку загострюється на 3-4 стадіях, а 5 категорія впроваджувачів уособлюють гомеостаз без прибутковості технологічного проекту в силу вирівнювання середньої норми прибутку. На стадї гомеостазу гама-патерн набуває статусу організаційного і апелює до ресурсу влади для патерналістських гарантій прибутковості. Культурні наративи ініціюють поведінкові патерни трансформації комериійної мрії у фінансові цінності шляхом зміни світу через IT-технологї. Наголошується, щуо апеляція гама-патерна до послуг ресурсу влади відбувається на мезорівні патерна влади, який теж являє собою патернальну тріалектичну конфігурацію: альфа-патерн знання, бета-патерн - сила та гама-патерн - багатство. Знання виступає організаційним патерном, бо воно пропонує нові проекти буття на основі розширених утилітарних сенсів людського існування. В індустріальну добу апеляція до влади породжувала авторитарні політичні режими та крупні монопольні об'єднання, а також забезпечувала синхронізачію та стандартизачію виробництва і розподілу. Сучасна изифрова економіка являє собою інформаційну мережу асинхронних біфуркацій часового ландшафту, де стандартизаџія як факт успіху периопрохідия, шео підлягає мімезису, спресовується в часі, поступаючись сегментації та персоніфікації інтелектуальних благ. Апеляція до ресурсу влади у постіндустріальній економіці формує особливий гомеостатичний патерн мезорівня базових патернальних тріад - “залізний закон олігархї”.
\end{abstract}

Ключові слова: чуттєва культура нігілізму, статична економічна ефективність, динамічна економічна ефективність, базові патернальні бізнес-тріади, інсайдерство нових комбінацій, організаційний альфа-патерн, гомеостатичний гама-патерн, патерн сили, багатства і знання мезорівня влади, синхронний i асинхронний ландшафт часу виробництва прибутку.

Shevchyk B. M.,

bmshevchyk@gmail.com, ORCID ID: 0000-0002-0004-325X,

Doctor of Economics, Professor, Professor of the Department of Economics, Lviv University of Trade and Economics, Lviv

\section{CULTURE, INNOVATION AND PROFIT IN STATIC AND DYNAMIC MODELS OF ECONOMIC EFFICIENCY}

\footnotetext{
Abstract. Peculiarities of economic systems functioning from the standpoint of their static and dynamic efficiency are considered. The influence of the dominant sensory culture of the West - nihilism - on the ways to ensure profitability from economic activity, in particular through technogenesis, is clarified. The impossibility to deduce the idea of development from the cognitive pattern of the normative standard of static efficiency - market homeostasis is substantiated. The market is interpreted as an informational mechanism to ensure the insiderism of new combinations in the mode of dynamic efficiency as the only condition for the company's profitability. Profit is interpreted as income for the production of information - a measure of the removed uncertainty of orderly existence, given in knowledge through the manifestation of qualitative properties of before non-existent things. The organizational status of the alpha-pattern of the
} 
Schumpeter's innovator in the structure of the trialectic paternal configuration of the microlevel of the basic paternal business triads is asserted. The function of the beta-pattern is performed by the venture capitalist, and the homeostatic gamma-pattern is performed by the marketer, who personifies the purpose of the system - the distribution and revenue appropriation from the products market sales. Insiderism of new combinations of innovative implementations trigger cumulative circles of growing profitability in the mode of innovations diffusion. The principle of distribution is closely related to the mentality of implementers: the maximum profit is received by implementers of 1-2 levels; competition in the market intensifies in 3-4 stages, and the 5th category of implementers represents homeostasis without profitability of the technological project due to the equalization of the average rate of return.. At the stage of homeostasis, the gamma pattern acquires organizational status and appeals to the resource of power for paternalistic guarantees of profitability. Cultural narratives initiate behavioral patterns of transforming a commercial dream into financial values by changing the world through IT-technologies. It is emphasized that the appeal of the gamma-pattern to the services of the power takes place at the meso-level pattern of power, that also represents a paternal trialectic configuration: alpha-patternknowledge, beta-pattern - power and gamma-pattern - wealth. Knowledge acts as an organizational pattern, because it offers new projects of existence based on the extended utilitarian senses of human existence. In the industrial age, appeal to the power gave rise to authoritarian political regimes and large monopolies, as well as provided synchronization and standardization of production and distribution. The modern digital economy is an information network of asynchronous bifurcations of the time landscape, where standardization as a fact of pioneer success, subjected to mimesis, is compressed in time, giving way to segmentation and personification of intellectual goods. The appeal to the resource of power in the post-industrial economy forms a special homeostatic pattern of the meso-level of the basic paternal triads - the "iron law of the oligarchy".

Key words: sensory culture of nihilism, static economic efficiency, dynamic economic efficiency, basic paternal business triads, insiderism of new combinations, organizational alpha-pattern, homeostatic gamma-pattern, pattern of power, wealth and knowledge of the meso-level of power, synchronous and asynchronous time landscape of profit making.

JEL Classification: A13, B49, O39, P16, P49, Z10
DOI: https://doi.org/10.36477/2522-1205-2021-62-06

Постановка проблеми. Одним із теоретичних здобутків сучасної економічної науки стало врахування впливу культури на економічне життя суспільства. Причому культуру трактують або як сферу економіки із товаризованою сукупністю послуг (бази відпочинку, музеї, театри і кіно, туристичний бізнес тощо), або як деструктивну екстерналію у вигляді архаїчних звичаїв, що гальмує економічний розвиток, або як етичний чинник трудових відносин, соціального капіталу та неформальних інституцій. Вкрай рідко трапляється розуміння економічної системи як культурного явища, де інституціональні патерни відтворення $є$ продуктами культурних наративів національного буття. Ще рідше спостерігаються спроби аналізу культурного середовища, яке сприяє економічному розвитку, а не гальмує його (окрім випадків спроб універсалізації утилітаристських ціннісних сенсів чуттєвої культури Заходу). С дослідження, присвячені впливу культури на економічний розвиток країн Південно-Східної Азії, Японії і Китаю. Подібні дослідження вкрай складно проводити щодо культурного контексту Східної Свропи. Проте слід знайти якийсь загальний незаідеологізований концепт для обгрунтування аналізу впливу культури на економічний розвиток, зокрема на інноваційні впровадження та можливості прибутковості.

Аналіз останніх досліджень і публікацій. Обрана тема визріла на міждисциплінарних стиках, передусім таких концепцій як тріалектичних патернальних конфігурацій К. Кантора, соціокультурної динаміки П. Сорокіна, статичної та динамічної економічної ефективності X. Уерта де Сото та Дж. Шумпетера, дифузії інновацій Е. Роджерса, впливу влади i знання на економічні процеси Е. Тоффлера і М. Кастельса та ін.

Постановка завдання. Статичність економічних систем обумовлена не гальмом культурних реліктів, як про це говорять адепти мейнстріму, а досягненням стану ринкової рівноваги в умовах повного використання усіх дефіцитних ресурсів. Ціль дослідження - шляхом виявлення логіки протікання соціентропії у статичній економічній моделі та обгрунтування джерел прибутковості у динамічній економічній моделі продемонструвати зрушення у структурі базових патернальних тріад мікрорівня соціокультурної динаміки на основі апеляції до атрактивних осередків мезорівня в умовах ринкового гомеостазу економічних систем. Для цього слід вирішити такі завдання:

розкрити механізм трансформації організаційного альфа-патерна в гомеостатичний гама-патерн в умовах статичної економічної ефективності;

обгрунтувати характер забезпечення прибутковості у біфуркаційній та гомеостатичній стадіях функціонування економічних систем;

пояснити необхідність ресурсу влади як атрактивного полюса мезорівня соціокультурної динаміки для збереження і відтворення гомеостатичного рівня функціонування базової патернальної бізнес-тріади макрорівня. 


\section{Herald of Lviv University of Trade and Economics. Economic Sciences. № 62, 2021}

Виклад основного матеріалу дослідження. У свідомості західної людини виник і утвердився технологічний смисл іï Буття: світ - це механічний агрегат усього раціонально упорядкованого та утилітарно підпорядкованого, де все вироблене через посередництво машини і призначене до конструктивного знищення у споживанні. Постала ілюзія безмежного панування над усім через застосування машини, що задала параметри екзистенціального горизонту смислу необхідності праці як товару - предмета доцільного і корисного руху у невідворотну точку свого небуття. Е. Северино пише: “Технології... постійно винаходять новий світ, що позбувається старого; вже не обмежуючись виробництвом споживчих товарів i нових робочих місць, вони спрямовані тепер на виробництво самої людини: іiі життя, відчуттів, думок, її ідеї досягнення добробуту і щастя. Маючи на меті звільнення людини від болю та смерті, технології претендують на ефективне виробництво того, що не могла забезпечити традиційна культуpa, а саме - Бога, зрозумілого як незаперечне володіння щастям. Смисл реальності - вже не просто об'єкт для міркувань, а те, що виробляється завдяки науковій діяльності” [4, с. 80-81].

Суб'єкт, який постійно винаходить новий світ через "нові комбінації”, позбуваючись водночас старого через “творчі деструкції, називається шумпетерівським підприємцем-новатором - організаційним альфа-патерном тріалектичної конфігурації базового мікрорівня соціокультурного буття - власне економіки. Він - ключова фігура біфуркації, імпульс розвитку, подвижник прогресу, котрий запускає кумулятивні кола добробуту на макроекономічному рівні та уможливлює вільну енергію чистої прибутковості економічної системи на мікроекономічному рівні.

Кожна економічна система - це сукупність механізмів та інституцій забезпечення виробництва, обміну і розподілу вартості і доходів у двох форматах господарських практик: статичної та динамічної економічної ефективності. Х. Уерта де Сото економічну науку розглядає крізь методологічну призму цієї дихотомії. В економічній теорії, яка інспірує економічні практики, домінує стандарт статичної ефективності - химера істини мейнстріму, яка породжує суперечності, ігноруючи їх. Панівний стандарт статичної ефективності передбачає, що на ринку досконалої конкуренції, де жоден учасник мінових трансакцій не може поліпшити функцію своєї корисності у формі грошової вигоди, не погіршивши при цьому становище інших учасників, усі ринкові актори володіють вичерпною і достовірною інформацією про обсяги наявних ресурсів та наділені адекватним знанням їх раціонального застосування у напрямі мінімізації енергетичних витрат. А це підштовхує до думки, що й когнітивні патерни оцінювання, які існують у свідомості учасників ринкових трансакцій, теж $\epsilon$ наперед заданими $\mathrm{i}$ в часі незмінними. Тому функції індивідуальної корисності реалізації максимально можливих переваг, відображених точками на шкалі виробничих можливостей, неможливо звести до спільного інтегрального знаменника можливості суспільного добробуту, бо кожна точка на кривій - це факт альтернативного вибору i оцінки цього вибору в умовах граничної продуктивності дискретно заданих факторів виробництва. Тому таке суспільство приречене існувати у вічному режимі “війни всіх проти всіх", бо реалізація однієї переваги заперечує можливість іншої, а отже провокує страждання проігнорованих та знехтуваних. Ця модель програмує необхідність аутсайдерів і моделює світ добробуту лише для обраних.

Статичний підхід до розуміння економічної ефективності як раціональної поведінки запобігання будь-якому марнотратному розтринькуванню енергії, акумульованої у дефіцитних ресурсах, Х. Уерта де Сото пояснює впливом технокультурного наративу чуттєвої культурної ментальності, а саме: механічної фізики. В основі фізики лежить поняття “енергії” - абстрактного поняття як емпіричного факту, котре проявляється як сила i рух. Енергія безконечно видозмінюється, постійно зберігаючись. Проте у процесах трансформації значна іiї частина розсіюється. Принцип живого у процесах адаптації зводиться до зусиль, пов'язаних iз запобіганням енергетичних втрат, розсіювання, власне ентропії як міри безпорядку. Ефективність почали розуміти як такий вид діяльності, що пов'язаний із мінімальними витратами 3-поміж усіх можливих способів виконання роботи для досягнення цілі. Причому і цілі, і засоби заздалегідь задані та дискретно фіксовані: ціль - максимізація корисності (по суті приріст енергетичного бюджету), а засоби - технології, що мінімізують розсіювання енергії. Х. Уерта де Сото пише: "Використання фізичних відкриттів на практиці було пов'язано $з$ інженерною справою на основі статичного поняття енергоефективності (або, на мові інженерів, “мінімізації енергетичних втрат”). Чудовою ілюстрацією може слугувати парова машина класичне капітальне благо Промислової революції. Парова машина трансформує тепло в рух і підняття вантажів; відповідно метою доброго інженера $\epsilon$ досягнення максимуму (статичної) ефективності, тобто максимального руху при мінімальних витратах і втратах енергії... Неокласична економічна теорія... лише замінила поняття енергії та поняття корисності» [7, с. 4]. Далі у тому ж дусі Х. Уерта де Сото наголошує: “Якщо технічна (або технологічна) ефективність означає мінімізацію виробничих ресурсів у фізичному розумінні (наприклад, тонн вугілля чи баррелей нафти), то вона практично не відрізняється від економічної ефективності, яка полягає в мінімізації ресурсів, але не в фізичному розумінні, а в розумінні затрат (котрі вираховуються як кількість використаних одиниць ресурсу, помножених на ринкову ціну одиниці)... Статичний підхід до економічної теорії зводить принцип економічної ефективності до суто технічної проблеми максимізації, котру завжди можна розв'язати 3 допомогою комп'ютера, ввівши в нього відповідні дані; адже усі моделі статичної ефективності вибудувані на ідеї, що всі дані вже наперед відомі” [7, с. 8]. 
Нормативний стандарт статичної ефективності передбачає збалансування потреби максимізації грошової вигоди в технологічних умовах мінімізації енергетичних витрат ресурсів завдяки раціонально осмисленій поведінці їх оптимального використання. Місцем цього практично збалансованого акту виступає ринок. Таким чином ринок це гомеостатичний механізм континуальної релевантної реалізації граничної корисності кожної одиниці товару до ринкової рівноважної ціни цього товару, обумовленої граничною продуктивністю дискретних факторів виробництва. Під цим кутом зору будь-яке винахідництво, будь-яке технологічне ноу-хау має одне-єдине призначення - посилення адаптаційного потенціалу системи 3 метою реанімації пониженого через невпинно зростаючі граничні витрати виробництва попередньо досягнутого рівня гомеостазу - акумульованого у поведінковий патерн інституціоналізованого досвіду відтворення прийнятно успадкованої форми соціокультурного буття. А де ж тут ідея розвитку як поява небувалого, буття нової сутності до того немислимого?

Статичне розуміння економічної ефективності не дозволяє бачити ринок як інформаційний механізм повідомлення про нові розширені горизонти небачених ніким раніше можливостей, про творчий підхід якісного вдосконалення мистецтва жити, про нові екзистенціальні стандарти способу і стилю життя людини у світі.

Отож, на ринку купуються і продаються товари, наділені атрибутом, який $є$ метою їх придбання - споживною вартістю як властивістю виробленої речі задовольняти людську потребу. Але кожна річ наділена невіддільною від буття сутнісною визначеністю - власною якістю. Ця якість є буттям “речіу-собі” і дається у пізнання шляхом проявлення своїх властивостей. Якість існує у речі завжди, а властивості проявляються для суб'єкта пізнання, який взаємодіє із цією річчю. Власне пізнання і $€$ процесом відображення властивостей речі у свідомості. Процесуальність - це маніфестація мінливості властивостей речі у часі перед очима розуму суб'єкта пізнання. Цей потік змін, що виникає i зникає, ця незбережувана сутність як міра кількості знятої невизначеності, що когнітивно упорядковує подієву континуальність буття визначеною комбінацією проявлених об'єктів, називається інформацією.

Отже, виходить так, що споживна вартість (або корисність) - це визначальна властивість товару, а властивість - це інформація. А значить: будь-який товаровиробник виробляє лише інформацію, навіть якщо виробляє матеріальні речі. Адже матерію він виробляти не може, бо вона - це нерукотворна та незнищима вічна сутність, формою руху якої $\epsilon$ енергія.

Д. Жилін пише: “Будь-яке виробництво зводиться до виробництва інформації... За вироблену інформацію виробник одержує платню. Та частина ціни товару, яку отримує виробник за вироблену ним інформацію, називається додатковою вартістю. Фактично, оплата - це теж інформація про наявність де-небудь інформації, яку може отримати одержувач оплати. Цікаво, що виробник одержує плату лише за інформацію, корисну споживачеві. Більше того, покупець буде платити передусім за найкориснішу інформацію. Дохід - це міра відносної корисності інформації для споживача... Корисність інформації для споживача виключно суб'єктивна і залежить від системи його цінностей. Тому будь-яка оплата суб'єктивна і залежить лише від споживача... Підприємець фактично отримує платню за створену ним структуру виробництва та інформацію про ринки збуту.... 3 усього вищесказаного випливають три важливі висновки. Поперше, чим більше загалом інформації, тим вона корисніша. По-друге, чим унікальніша інформація, тим вища іiі корисність. По-третє, чим більше інформації у підприємця про систему цінностей споживача, тим вищою $є$ ймовірність виробництва ним корисної інформації. Тому найзаможнішими будуть виробники величезної кількості унікальної інформації. Узагальнюючи: виробник потужних комп'ютерів завжди буде незрівнянно заможнішим, аніж здобувач піску, нафти і руди, 3 яких ці комп'ютери виробляються" [1, с. 69].

Зі сказаного виснуємо, що підприємець отримує прибуток як плату за виробництво інформації, за реалізовані можливості нових властивостей ширшого віддзеркалення якості дочасно прихованого буття - нової дійсності, а не як рекомбінацію точок на кривій виробничих можливостей шляхом раціонального переосмислення використання обмежених ресурсів в режимі їх енергоощадливості. Саме ця ідея, за Х. Уерта де Сото, лежить в основі економічної концепції динамічної ефективності.

Ця концепція грунтується на ідеї про розширені виробничі можливості на основі інноваційних технологій, про сферу застосування яких через сигнатуру цін інформує ринок. Інформація про ці можливості розпорошена і не проявлена, iї має виявити підприємець-новатор, застосувавши креативнотворчий підхід невідомого досі способу прибутковості. Тому ринок реалізує дві функції: гомеостатичну та біфуркаційну. Перша - як патерн стандарту статичної ефективності - демонструє рівноважні стани мінових співвідношень граничних корисностей і граничних продуктивностей в умовах інформаційної визначеності та вичерпності опредметненого досвіду відтворення потоків вартості через дифузійний мімезис технологій. Друга функція ринку - це забезпечення інституціональної структури сприяння підприємницькій ініціативі нових виробничих комбінацій ресурсів у формі етичних принципів виробничих відносин інтегральних контурів посилювальних та обмежувальних зворотних зв'язків у визначених патернальних конфігураціях кумулятивного способу максимізації прибутковості. Саме так, на думку Х. Уерта де Сото, трактували ринок як інформаційний механізм динамічної ефективності представники неоавстрійської школи: Л. фон Мізес, Ф. фон Гаєк, I. Кірцнер та М. Ротбарт. I на цій підставі Х. Уерта де Сото цілком слушно долучає до зазначеної плеяди також і Дж. Шумпетера (до того ж, 


\section{Herald of Lviv University of Trade and Economics. Economic Sciences. № 62, 2021}

теж австрійця за походженням). Останній наголошував на двох наративах способів економічної діяльності: $з$ одного боку, - “середовище постійно пропонує нові можливості” [8, с. 86], а 3 іншого, “в економічному житті кожен крок, який виходить за межі заведеного порядку, шаблона, пов'язаний із труднощами й елементом новизни. Саме цей елемент і лежить в основі явища лідерства" [8, с. 91]. Існуючі інституціоналізовані патерни раціонального досвіду способів виробництва - це деталізовані інформаційні проекти “зробленого, побаченого i пережитого” [8, с. 92], які характеризують фах менеджера, а не підприємця, плід уяви якого надає йому “надлишок сил понад щоденну потребу” [8, с. 93] для "втілення величезного розумового зусилля" [8, с. 90]. “Втілювати новий план, - пише Дж. Шумпетер, - та діяти за звичним шаблоном це так само різні дії, як прокладання дороги та ходіння нею" [8, с. 92].

Теоретичні уявлення про статику і динаміку в економічній науці Дж. Шумпетер вважав “скороченими варіантами теорії економічного колообігу та теорії розвитку" [8, с. 90]. На його думку, статичний підхід дозволяє “дослідити нове рівноважне положення після усіх змін, що відбулися” [8, с. 72]. Натомість розвиток - це “спонтанні й дискретні зміни у шляхах перебігу економічного життя, порушення рівноваги, які назавжди змінюють i замінюють попередній стан рівноваги" [8, с. 74]. Втілення нових комбінацій Дж. Шумпетер трактував власне розвитком - появою нової сфери буття: нової якості речей, нової етики потреби, нового способу виробництва, нового ринку, нових джерел ресурсів і нових технологій - і все це реалізується дискретно, підвищуючи рівень гомеостазу настільки, що кількісними модифікаціями раціоналізації статично заданих ресурсів його сягнути неможливо. "Постійне вдосконалення поштових диліжансів ніколи не приведе до появи залізничного потяга”, писав Дж. Шумпетер [8, с. 74].

Суб'єкт-ініціатор нових комбінацій - власне підприємець-новатор - це не суб'єкт раціональної економічної поведінки; він - не гедоніст, його мотиви ірраціональні; він амбітний, але не егоїст; прибуток для нього - не мета, а винагорода за "розкіш ризиком" у будівництві "власного царства" [8, с. 99]. Як автор проекту розвитку, шумпетерівський підприємець-новатор висуває якісно нову вдосконалену і розширену утилітарну модель можливого добробуту i впроваджує ii шляхом "створення нової купівельної спроможності з нічого" [8, с. 81]. Підкоригуємо: створення нової купівельної спроможності - $з$ ідеї.

Отже, у структурі базової патернальної тріалектичної конфігурації мікрорівня соціокультурної динаміки шумпетерівський новатор - це організаційний суб'єкт альфа-патернальної структури. Не маючи нічого, крім мрії, він розпочинає 3 дивного вчинку: стає “боржником суспільства”, аби в майбутньому стати його кредитором, реалізуючи “вимоги на соціальний дивіденд” [8, с. 107]. Тисячоліттями цивілізація практикувала споживчий кредит на основі майнового забезпечення для потреб “вести” бізнес, на відміну від “заснувати” бізнес [8, с. 109]. У першому випадку отримувач не вважався “боржником суспільства” згідно з логікою процесу розвитку [8, с. 108]. Кредит сприяє промисловому розвитку лише в тому випадку, коли не просто “засвідчує очікування майбутніх послуг чи ще не вироблених товарів", а виступає “платіжним засобом, якому поки що ніщо не відповідає" [8, с. 107]... окрім мрії змінити світ через технологію. Шумпетерівський підприємець - це продавець мрій, де первинним платіжним засобом, базовим внеском купівельної сили можливості нового постає віра. I тим суб'єктом віри, посвяченим неофітом містерії нового світу, стає "ефор ринку" [8, с. 82] - банкір, який від імені суспільства “довіряє виробничі сили” [8, с. 112] альфапатернальному суб'єкту бізнес-тріади. Тому банкір, зокрема венчурний капіталіст, - це суб'єкт бетапатернальної конфігурації, який фіктивним чином забезпечив нову купівельну спроможність для знання нових можливостей стати реальністю матеріального добробуту суспільства.

Економічна інновація стосується поліпшення умов життя у майбутньому, яке, з одного боку, бажане, а з іншого, - невизначене. I ця невизначеність, за Дж. Шумпетером, генерує два види ризику: технічного провалу i комерційного краху. Ймовірність цих викликів створює напруження між технічним та комерційним менеджерами компанії: технологічні зміни до виробничого процесу аналізуються з позицій окупної доцільності капіталу, зокрема - комерційного зиску. I тут на перший план виходить третій гама-учасник мікропатернальної бізнес-тріади - маркетолог. У дихотомічному режимі функціонування ресурсу праці: “керівна - керована", він остаточно уособлює першу, приймаючи рішення, яке, по суті, і $є$ метою функціонування бізнес-тріади - отримання прибутку, максимально можливого 3-поміж усіх варіантів альтернативного вибору “вартість - витрати”. Він керується значно “приземленішими” мотиваціями: не змінити світ через ноу-хау, а “вичавити” прибуток в умовах наростаючих тенденцій гомеостазу вирівнювання середньої норми прибутку. Але чому так відбувається?

Прикладне призначення інновації в економіці збільшити у кількісному вимірі благ і якісному вимірі буття матеріальний добробут суспільства через застосування нових виробничих технологій. У такому випадку суспільний добробут постає як емерджентний ефект явища дифузії інновацій. Е. Роджерс визначає дифузію інновацій як комунікаційний процес, у якому з плином часу повідомлення про нові ідеї, як проекти інструментальних дій зменшення каузальної невизначеності на шляху до інтегрального способу максимізації індивідуальної корисності, поширюється інституціоналізованими каналами серед членів соціальної системи, формуючи технологічні кластери соціальної дії [3, с. 25]. Е. Роджерс звертає увагу на цікаву деталь: більшість індивідів, намірених впроваджувати інновацію у власне виробництво, оцінюють перспективи зростаючої прибутковості не на основі 
науково-теоретичних розрахунків, а керуючись суб'єктивним оцінюванням досвіду попередників, тобто шляхом міжособистісних комунікаційних зв'язків, а не холодною рафінованою логікою раціонального обрахунку грошової вигоди [3, c. 39]. А це означає, що процес дифузії інновацій, як поширення технологічних змін у господарських практиках, залежить від ментальності суб'єктів мімезису, що й зумовлює їх класифікацію на п'ять категорій впроваджувачів: 1) новатори; 2) ранні впроваджувачі; 3) рання більшість; 4) пізня більшість; 5) забари [3, с. 59]. Е. Роджерс так характеризує цих особистостей:

1. Новатори - сміливі, “одержимі ризиком” [3, c. 315]. У їхньому середовищі переважають загалом дружні стосунки однодумців. У ринкових нішах гомеостазу вони виразно бачать нові можливості і наділені пасіонарною рішучістю долати інформаційну невизначеність. Їх соціальна роль - “імпортування інновацій з-поза меж системи і запуск нових ідей в системі” [3, с. 315].

2. Ранні впроваджувачі - шановні. Вони ментально суттєво різняться від новаторів: якщо перші - це “космополіти” [3, с. 315], які “не мають опертя у формі культурної традиції [8, с. 96], “ламають старі традиції та створюють нові” [8, с. 98], то "ранні впроваджувані прив'язані до своєї місцевості” [3, с. 315]. Вони активно консультують колег як знавці мінімізації невизначеності, “уособлюють успішне, виважене застосування нових ідей” [3, c. 316]. Вони - авторитети суб'єктивного оцінювання, які ставлять “печатку схвалення" [3, c. 316] у подальшому процесі дифузії інновацій.

3. Рання більшість - помірковані. Це ті, хто впроваджує у виробництво нові технології, обачно зважуючи власні рішення. Вони - не лідери, але і не аутсайдери. Вони доволі чисельні - понад третина членів системи [3, с. 316]. Вони підтримують міжособистісні зв'язки, а отже наратив конкурентної боротьби ще не воздомінував. Проте ця поміркована рання більшість виявляє одну ментальну властивість, яка засвідчує про наростання гомеостатичних тенденцій вирівнювання прибутковості: певний час вагаючись і зважуючи доцільність рішення щодо впровадження ноу-хау, ця категорія підприємців, за визначенням Р. Талера, керується "ефектом ендаумента" - ціна можливості визначається ціною втрати попередньо набутого, тобто ціна володіння вище, ніж ціна ризику [5, с. 21-23]. Ця деталь говорить про гармонійний, а не пасіонарний тип ментальності членів поміркованої ранньої більшості. Вони ніколи не належатимуть до тих шибайголов, які “розкошують ризиком”, щоб "збудувати особисте царство... успіху заради самого успіху, а не його плодів" на основі “мрії і волі" $[8$, c. 99$]$.

4. Пізня більшість - скептики. Їх теж чимало, як і поміркованих - третина. До впровадження інновації їх спонукає “економічна необхідність та наростаючий тиск з боку інших членів системи” [3, c. 317]. Вимушена спонука свідчить про нав'язувану адаптивність, аби нівелювати ефект конкурентної переваги попередників. Тобто на цьому етапі загострюється конкурентна боротьба. Е. Роджерс зазначає, що коли до діла беруться “скептики”, то “інновація вже має усталитися як норма для системи” [3, с. 317]. Тобто виробництво вже втрачає переваги інноваційності у сенсі чистої прибутковості, де невизначеність подолана не ризикованим авантюризмом пасіонарія, а інституціоналізованим патерном виробничих відносин.

5. Забари - традиціоналісти, останні впроваджувачі з “найбільш провінційним світоглядом” [3, c. 317]. До переоцінки власного ендаумента їх штовхає крайня необхідність: детенсивний характер власного виробництва, технологічно нерентабельного, коли капіталомісткість граничної одиниці капітального блага перевищує його капіталовіддачу, що $\epsilon$ прямою $\mathrm{i}$ гарантованою дорогою до банкрутства. Забари технологічно адаптуються вкрай вимушено, через безпосередню загрозу краху свого бізнесу.

Помірковані, скептики і забари демонструють поведінкові патерни раціонального мислення в умовах оптимуму Парето. Усі вони, передусім скептики і забари, функціонують в умовах ентропійного режиму виробництва на ринку досконалої конкуренції, коли гранична продуктивність граничної одиниці капіталу дорівнює вартості кінцевого продукту, підприємці при цьому не вбачають технологічних способів альтернативного застосування наявного капіталу, а сукупна пропозиція товарної маси даного техногенного способу виробництва увійшла в режим спадної граничної корисності споживчих благ, що виробляються. Вартість відображає зростаючі граничні витрати, а спадна гранична корисність, що відображає максимальний ступінь насичення, унеможливлює прибутковість. Дж. Шумпетер писав: “Отримуємо парадоксальний факт: у найдосконалішому своєму стані економічна система працює без прибутку” [8, c. 45].

Але ж є суб'єкт бізнес-тріади, який відповідає за прибуток будь-якою ціною, - це маркетолог. Справа в тому, що на рівні “пізніх впроваджувачів" в інституціоналізованому полі виробничих відносин відбувається одна важлива метаморфоза, яка надалі виявляє свій ентропійний деструктив: гомеостатичний гама-патерн витісняє на маргінес i заміщує собою у статусі організаційного альфапатерн.

Чим ближче до гомеостазу, тим жорсткіша боротьба за прибуток, а грошовий наратив постає єдиною домінуючою мотивацією, виключаючи будь-яку атрактивність. Ці тенденції у сфері сучасних комп'ютерних технологій відобразив М. Кастельс. Якщо індустріальні технології створювалися з метою зміни світу, то цифрові технології - 3 метою зміни уяви, становлення віртуальних світів, де когнітивний досвід міри пізнаної істини контрсублімовано до емоційного катарсису вивільненого інстинкту. Так, наголошує М. Кастельс, культура $є$ джерелом ідей, без яких люди не діють, а діяльність передбачає орієнтування на набір цінностей [2, с. 54]. На його думку, рушійною силою Інтернет-економіки $€$ підприємницька 


\section{Herald of Lviv University of Trade and Economics. Economic Sciences. № 62, 2021}

інновація - інвестиція капіталу у мрію, через що венчурні капіталісти (бета-патернальні суб'єкти бізнес-тріад) виступають “охоронцями джерел створення нового багатства”, які “ненавидять один одного” [2, с. 56]. М. Кастельс підкреслює, що IT-підприємець - це жива антитеза суб'єкта пуританської етики. Творення майбутнього через технологію, а не передбачливі заощадження аскетичної поведінки, гарантують безпеку життя. Імператив споживання емансипував від наративу відтермінованої винагороди старої буржуазної культури, де прибуток поставав із свідомої жертви утримання. М. Кастельс пише: "Наріжним каменем підприємницької культури Силіконової долини та всієї Інтернет-галузі стала реалізація потенціалу перетворення сили інтелекту на засіб одержання прибутку. Ідеї продавалися венчурним капіталістам, відкриваючи тим самим доступ до інвестицій, які перетворювали ці ідеї у бізнес. І ці ідеї... продавалися інвесторам шляхом відкритого продажу на фондовій біржі... Це культура, в якій найвищими цінностями є сума грошей, яка має бути зароблена, i швидкість, із якою ці гроші заробляються.... Отримання прибутку стає мірилом успіху, i, що важливо, мірилом свободи напротивагу традиційному корпоративному світові. Єдиний спосіб для підприємців звільнитися від влади капіталу - це здобути можливість самим залучати капітал, і робити це так, щоб можна було контролювати достатньо велику частку майбутнього багатства, яке може надійти від інвесторів. Ось чому фундаментальним механізмом, який пов'язує особисту свободу та підприємництво, є фондові опціони.

У світі, який аж кипить від інновацій, єдиним способом виміряти конкуренцію та здобути повагу рівних собі, а також примусити корпоративний істеблішмент боятися тебе, $є$ гроші... Тоді як фінансові інвестори намагаються заробити гроші, прогнозуючи майбутню поведінку ринку чи просто знаючи іiі, Інтернет-підприємці продають майбутнє, бо вони вірять, що вони можуть його створити... вирішальна позиція полягає в тому, щоб спочатку переконати фінансові ринки, що майбутнє саме в цьому, а потім спробувати продати технологію користувачам... А стратегія - це зміна світу через технологію, а тоді вже відповідна нагорода грошима та владою завдяки напрацюванням фінансових ринків. Базисом цієї підприємницької культури $є$ здатність трансформувати технологічне ноу-хау та комерційну мрію у фінансову цінність" [2, с. 55].

IT-підприємництво, за М. Кастельсом, - це культура жадібних до грошей трудоголіків, “грошей у неймовірних кількостях” [2, с. 56]. Особливістю цього виду технологічної творчості $\epsilon$ “злиття ідей, праці та особистого накопичення багатства в єдиному процесі” [2, с. 56]. Ця культура “глобально поліетнічна" [2, с. 57]. Вона поєднує абсолютистські прагнення індивідуальної свободи iз служінням “золотому теляті” як символу особистого тріумфу. Це культура “швидкісних стандартів життя... в несамовитому темпі”, де “особисті стосунки - це скоріше інструмент, а не емоції' [2, c. 57]. Вражає їх показово надмірне споживання, жага до розкоші для іiі публічної маніфестації, оскільки сам трудоголік має небагато вільного часу насолоджуватися маєтностями. Сучасні ITпідприємці чимось нагадують вебленівський “бездіяльний клас" кінця XIX - початку XX ст. I нагадують його заповзятим виставлянням напоказ життєвих вигод та пишноти. Проте є одна суттєва різниця: “айтішники” фактично позбавлені дозвілля у сенсі невиробничого проведення часу. Їхня діяльність полягає у продукуванні нових сенсів із ресурсів цифрових технологій та перетворенні технологічного досвіду у буденні практики, аби шляхом закріплення сенсу як культурного тексту зманіфестувати власну ідентичність у ії соціальній значущості, нібито кинувши виклик пристосуванству, проте залишаючись підконтрольними та підпорядкованими гедоністичній цинічно-чуттєвій культурі. Їх талант - хист постійної здатності творити технології - $\epsilon$, з одного боку, латентним прагненням до безсмертя, а 3 іншого, - “соціальним аутизмом" [2, с. 58], оскільки це той вид “творчої деструкції”, що породжує "руйнівне творіння", яке використовує цинізм і нігілізм особистого життя як матеріал виробництва ідей штучно сконструйованого світу, аби надалі перетворювати його у практичний зиск грошової вигоди, сума якої перевершила б усі попередні. Їхнє “споживання напоказ” - це не лише демонстрація особистого життєвого успіху “самоствореної людини” чи оцифровленої постлюдини, що передбачає подальший мімезис трибу життя як поведінкового патерна та породжує стиль і смак у культурі. Це компенсація приховуваної деструктивності через постійне виробництво технології псевдовітальної віртуалізації, яка нав'язує дійсність взаємовідчуження людини від людини, дійсність міжособистісненого знелюднення, де диктат вимоги грошової репутації, виражений купівельною спроможністю надмірної дорожнечі ужиткових речей, намагається водночас і приховати, і проявити збочену волю до влади над світом.

Отже, за М. Кастельсом, культура ІТ-підприємництва - це культура відкритої технологічної творчості, втілена у віртуальних мережах співтовариствами хакерів та матеріалізована IT-маркетологами, де бізнес використовує цифрову інформаційну мережу 3 “електронною нервовою системою” [2, с. 63] в якості своєї організаційної форми максимізації прибутковості. М. Кастельс наголошує, що коли фірма і надалі залишається одиницею накопичення капіталу, прав власності та стратегічного управління, то комерційна діяльність реалізується спеціально створеними менеджерами, де комерційний менеджмент нагадує “змінну геометрію кооперації та конкуренції” [2, с. 65]. Більше того, розвиток інноваційно-цифрових технологій не лише лавиноподібно пришвидшує моральне зношення основних засобів виробництва, а спрямовує інтелектуальні зусилля у напрямку винайдення такої машини, потужності якої відповідатимуть нульовим граничним витратам, капіталовіддача не передбачатиме фондозаміщення. Тобто здійсниться стара індустріальна мрія винайдення машини 3 “вічним двигуном”, яка в умовах інформаційних 
технологій вже не утопія, а потенційна можливість, бо інформація, на відміну від енергії, одискретнена відносно, а не абсолютно. Тоді весь тягар конкурентної боротьби за прибутковість буде перенесено у віртуально-мережевий простір комерційної діяльності, а не у виробничу сферу, як в індустріальну епоху. I вже замало буде маркетингового мистецтва спокуси звабити покупця через диктат реклами, запустити біологічну реакцію ментальності на еталонно нав'язувану поведінку через спонуку придбання речі, кожна з яких є порталом псевдоініціації входження людини у світ споживання як сенсу існування. Загострення конкуренції у цій сфері призведе до естетичного розбещення смаків споживача у просторі потенційної дешевизни безупинно “старіючої” продукції через постійно прогресуючий техногенез та невпинне наближення виробничих технологій до параметрів нульових граничних витрат. I, як завжди було в історії, жага до омріяної стабільності як умови безтурботної максимальної прибутковості (чого понад усе жадає гама-патерн тріалектичної бізнес-конфігурації) все голосніше апелюватиме до ресурсу влади як джерела і запоруки багатства.

Мезорівень патерна влади слугує атрактивним середовищем для мікрорівня базових патернальних бізнес-тріад. Гомеостатичний гама-патернмаркетолог у статусі організаційного здатний продукувати патернальні проекти відтворення у середовищі домінуючої культури та забезпечувати саме цього типу креативними ресурсами прибутковість своєї справи. Продукувати парадигмальні проекти розвитку, які б не лише технологічно змінювали довколишній світ, а й екзистенціально вдосконалювали б людину у ньому, і щоб забезпечували при цьому не короткострокові конкурентні переваги прибутковості в умовах вирівнювання середньої норми прибутку внаслідок вільного залучення та напливу конкурентних капіталів, а давали б довгострокову насолоду пожиттєвою моральногрошовою рентою за фундаментальний внесок у розвиток цивілізації, - гама-патерну не дано. Скільки б він не чинив когнітивні чи праксеологічні акти спротиву тискові соціокультурної системи, він буде іiї приреченою жертвою і іiі продуктом, що знає лише іiі як єдиний безальтернативний формат світу і буття у ньому: він іiі “блудний син”, іiі Едіп і їі Прометей. I коли процес дифузії інновацій ввергне економіку в гомеостатичний режим статичної ефективності усередненої норми прибутковості без власне прибутку, бізнес виявить попит на владу. Але це буде бізнес, представлений гама-маркетологами у статусі суб'єктів організаційних патернів.

Мезорівень патерна влади, як і мікрорівень базових патернальних тріад, теж має тріалектичну патернальну структуру, яка функціонально та процесуально протікає поміж двох атрактивних осередків: інклюзивних та екстрактивних соціальноекономічних інститутів. Тріалектична структура патерна влади включає: наукове когнітивне знання як організаційний патерн, політичну силу державного апарату як патерн-підсилювач, матеріально-грошове та статусно-символічне багатство як гомеостатичний патерн.

Кожен знає, що влада - це можливість впливати, підпорядковувати потребам служіння, чинити примус під вивіскою закону, перетворювати чужу волю і чуже життя у ресурси своїх амбіцій. Влада це сила розподіляти i перерозподіляти енергію життя на свою користь. Але відповідь Христа Пилатові спонукає до роздумів про першоджерело влади: усвідомлювати владу як надану можливість керувати самим собою. Е. Тоффлер трактує владу як універсальний вимір усіх людських стосунків, що $є$ оберненою величиною бажання. Тому усе те, від чого залежить здійснення бажання, є потенційним джерелом влади. I таких джерел влади Е. Тоффлер виділяє три: сила, багатство і знання [6, с. 31]. Насильство, вжите навіть як кара за злочин, - це завжди “влада низької якості” [6, с. 34]. Натомість високоякісна влада - це переконати інших вподобати поставлені їм цілі, сприйняти їх як власні, усвідомити необхідність обов'язку, а в ідеалі - перетворити його у предмет власного бажання, полюбити образ світу, не здогадуючись, що він нав'язаний і ретранслює чужу мету як власну. Влада середньої якості, за Е. Тоффлером, - це багатство, коли за гроші можна купити все, крім безсмертя, бо розвіється навіть пам'ять, коли промине життя або спорожніє гаманець. Сила і багатство можуть забезпечити оволодіння владою: банкіри можуть стати королями, як Медичі. Але преображення влади, глибинні зрушення у способах впливу збудувати світ новий і виплекати нову людину у структурі цього світу, - на це спроможне лише знання.

Е. Тоффлер виділяє такі характеристики знання: воно невичерпне; воно лежить не лише в основі влади, а й сили і багатства; але воно може належати слабким і бідним і через те становити загрозу існуючій владі, зокрема владі багатства; воно - показник найсуттєвішої диференціації людей, бо “хоч яка прірва роз'єднує заможних і бідних, а ще більша безодня лежить між... невігласом й освіченим" [6, с. 39]; воно - суть будь-якої конкурентної боротьби, адже контроль над розумом через інформаційний вплив - це найдієвіший ресурс збереження і відтворення влади прихованого панування та невідчутного підкорення.

Оволодіння, за Е. Тоффлером, завжди передує творенню. Тому “в еру заводських димарів... сукупна маєтність... походила від організації дешевої праці, сировини та виробництва устаткування" [6, c. 45]. Економічне знання зводилося до обгрунтування доцільності зміщення точок на кривій виробничих можливостей в умовах статичної ефективності на ринку досконалої конкуренції. I ця міфологема, підживлювана “фрідманівськими хлоп'ятами”, поширила уявлення про економіку як “безлику машину, що знає лише попит і пропозицію - й нехтує роль влади у створенні багатства й прибутку" [6, с. 50]. Тому професійним економістом може бути навіть папуга, який навчився вимовляти два сакраментальні слова: “попит” і “пропозиція”. Але в умовах статичної ефективності саме ресурс влади 


\section{Herald of Lviv University of Trade and Economics. Economic Sciences. № 62, 2021}

“найчастіше впливає на рівень прибутку потужніше, ніж дешева робоча сила, нові технології або раціональний економічний розрахунок” [6, с. 52].

Оскільки бізнес залежав і залежатиме від закону, який є “сублімованим насильством” [6, с. 62], попит на монополію сили завжди буде присутнім. 3 іншого боку, внаслідок того, що капіталізм перетворив соціуми у ринкові системи, гроші стали “первинним знаряддям влади” [6, с. 65], по суті культурним наративом - заданою екзистенціальною модальністю оцінювання утилітарних сенсів буття.

Але що таке гроші як ресурс влади для забезпечення невпинного зростання багатства? Школяреві відомо, що гроші - це передусім інформація про величину мінової вартості продукту праці. I порції цієї інформації роблять обмін еквівалентним - обмінюються речі на основі кількісного співставлення обсягів трудових зусиль. Ось вона - матеріалізована справедливість у практиці людських відносин.

Е. Тоффлер відомий як автор ідеї Трьох хвиль Промислової революції. Гроші Першої хвилі - монети з благородних металів - мали власну внутрішню цінність, яка “залежала від їхньої ваги, а не від карбованих на ній слів” [6, с. 92]. Гроші Другої хвилі - паперові банкноти - це символічні репрезентанти вартості все ще у своїй дотикальній матеріальній формі, які задовольняють споживчі та інвестиційні потреби, коли їх позбуваєшся. Тут вже ключову роль відіграє інформація-номінал. Фундаментальна різниця між грішми Першої і Другої хвиль полягала в тому, що другі вимагали суспільної довіри. Як державні казначейські білети, вони були борговими квитанціями держави, наділені державною гарантією, запевненням, підкріпленим авторитетом влади, що емітовані нею шматки паперу виконуватимуть функції міри вартості, засобу обігу та збереження цінності в часі в межах простору політичного суверенітету. Гроші Третьої хвилі це електронні імпульси розрахункових комп'ютерних мереж, відеоявище, недотикальний рукою інформаційний потік. Це гроші символічні, навіть “надсимволічні" [6, с. 93]. Вони повністю емансиповані від матеріальної основи і зосереджені виключно у віртуальному просторі - пам'яті комп'ютера. I вони гранично емансиповані від часових обмежень мінових трансакцій. Електронні сигнали уможливлюють привласнення і споживання матеріальних благ. Багатство стає символічним: якщо монета постала як еталон міри вартості будьякої речі, де обсяг трудових зусиль передбачав можливість обміну товару на товар в еквівалентних пропорціях, то банкнота - це репрезентант цінності речового вмісту монети, іiі знак, похідне (надалі похідне праці, закладеної в товар). Натомість електронні імпульси - це похідне від похідного, “відбиток у нескінченному коридорі свічад” [6, с. 86], вартість із невловимою субстанцією.

Для будь-якого бізнесу, скрізь і завжди, час це прихований актив продуктивності. Час - це дійсно гроші. Перегони за скорочений час виробничого циклу - суть конкурентної боротьби. Мистецтво реорганізації виробничого часу - основна умова зростання багатства. Ритм часу примножував матеріальне багатство індустріального суспільства через синхронізацію та стандартизацію виробництва.

"В ідеально синхронізованому світі, - пише Е. Тоффлер, - товарне виробництво налагоджено так, що будь-які витрати: вартість зберігання, обслуговування, управління транзитом - зведено до нуля" [6, с. 69]. Синхронізація утримує ключові змінні у фіксованому стані, час ніби стає підконтрольним, передбачуваним в оцінюванні, прогнози увиразнюються у результатах, зберігається постійність співвідношення витрат і кінцевого продукту. Синхронність ніби не залишає місця для невизначеності, створюючи передумови постійності і стабільності у виробництві прибутку. Проте синхронізація робить систему нееластичною до змін, вразливою перед викликами та інертною щодо інновацій. Синхронізація, архетиповим патерном якої виступав фордівський конвеєр індустріальної доби, творила багатство через узгоджені ритми ланцюгів вартості часової синергії, де стиснення часу у виробничому циклі нових комбінацій “ресурси $\rightarrow$ продукти” не продукувало аритмії “ландшафту часу” економічної системи, бо винахідництво носило перманентний характер, а процес інноваційного впровадження передбачав суттєвий часовий лаг заміщення основного капіталу. Тривалість часу передбачала проективне оцінювання капіталовіддачі 3 мінімізованою певністю похибки. Коли оцінюєш перспективи змін соціальної системи на основі економетричних критеріїв механістичної системи, час піддається стандартному розфасуванню чіткості поетапних впроваджень. Але суспільство - це не механізм, а організм, і з'являються такі екстерналії, які перевертають звичні уявлення “з ніг на голову”. Зокрема, фактором конкурентних переваг все більше виступає аритмія “ландшафту часу”, яка спресовується у мить: а) виробництва (не перманентного, а постійного) наукоємно-інноваційних технологій та б) миттєвого, невідтермінованого їх споживання (адже спресування часу виробничого циклу до миті інтелігібельного одкровення нівелює часовий лаг між утилітарною придатністю, очікуванням і задоволенням від споживання у середовищі покупців). У режимі реального часу у напрямку його стиснення до миті, де в одночассі поєднується впровадження, виробництво і споживання, а також i відтворення (все рідше і рідше), за Е. Тоффлером, рухається знання, продиктоване новітнім наративом багатства суспільства цифрової економіки: мить “до” коштує дорожче, ніж мить “тут-і-тепер”, бо включає усю сукупність альтернативних вартостей нереалізованих можливостей примноженого багатства [6, с. 87]. Але є і зворотний бік: “комерційний ландшафт весь вкритий “уламками” нереалізованих фантазій”, - наголошує М. Кастельс [2, с. 62]. Цифрова економіка має “особливу нервову систему" - інформаційну мережу асинхронних біфуркацій часового ландшафту, і цим відрізняється і від механічного агрегату, і від біологічного організму: по-перше, неймовірно ускладнюється не 
лише термін оцінювання споживної вартості когнітивного капіталу, а й власне сам час такого оцінювання через постійне і невпинне оновлення інноваційного знання у структурі вартості робочої сили; по-друге, у структурі “великих конкурентних перегонів" неможливо оцінити те, чого ще не існує (потреба у ньому є, а проекту, навіть образної ідеї, нема і невідомо, чи буде), бо невідомо коли в голову вченому прийде інвестиційно бажана новаторська ідея, і чи прийде взагалі; по-третє, форматом "відповіді" на “виклик” “стиснення часу” стала персоніфікація виробництва, перехід до “персоніфікованих продуктів і ринків” [6, с. 88]. Надалі ми обгрунтуємо потенціал “наріжного каменя" становлення нооекономіки цього третього пункту.

Другою умовою прибутковості, поруч із синхронізацією, слугувала стандартизація, бо конвеєр без стандарту - це форма хаосу. Стандарт упорядковує заміщення в часі. Але стандарти задає першопроходець, чим уможливлює кумулятивні кола дифузії інновацій - власне економічне зростання. Тому стандарт - це знак перемоги і слід звитяжця в економічній історії. Дифузія інновацій передбачає мавпування стандарту або в режимі “летючих гусей”, або “глухого кута". Е. Тоффлер наголошує, що битву за стандарти нікому і ніколи не вдасться виграти [6, с. 173]. І ось чому: по-перше, конкуренція у сфері когнітивного капіталу передбачає започаткування альтернативної стандартизації технологічного ноу-хау; по-друге, розширюється поле свободи споживчого вибору, що дозволяє користувачеві змінювати використовувані системи; потретє, сегментаризація у напрямку персоніфікації інтелектуального продукту усуває стандарт як явище масового вжитку на другий план. Стандарт еволюціонує у когнітивний патерн, інструмент впливу на свідомість, нав'язаний спосіб мислення для контролю над розумом, ментальний конструкт реалізації волі латентного архітектора вибору.

Асинхронізація ландшафту часу у сфері стандартизації, що породжує лише стабільність нестабільності, змушує систему багатства знову апелювати до ресурсу “сила". В індустріальну епоху ця апеляція породжувала могутні монополії та авторитарні політичні режими, а в постіндустріальну проявляється як самовідтворювальний патерн “залізний закон олігархії.

Висновки та перспективи подальших досліджень у даному напрямі. Напрямки подальших досліджень можуть стосуватися аналізу макрорівневої атрактивності соціокультурних систем, обумовленої екстрактивними та інклюзивними економічними інститутами. А також можуть стосуватися більш поглибленого пошуку способів збереження гомеостазу економічної системи ресурсами політичної влади. I врешті-решт слід зосередити увагу на дослідженні тієї сукупності інноваційних впроваджень, які зумовлюють біфуркацію і зміну домінуючого типу культури, зокрема заміну чуттєвої культури на ідеаційну.

\section{ЛІТЕРАТУРА}

1. Жилин Д. М. Теория систем: опыт построения курса / Д. М. Жилин. - М. : КомКнига, 2006. $184 \mathrm{c}$.

2. Кастельс М. Інтернет-галактика. Міркування щодо Інтернету, бізнесу і суспільства / М. Кастельс. - К. : “Видавництво «Ваклер»” у формі ТОВ, 2007. -304 c.

3. Роджерс Е. Дифузія інновацій / Е. Роджерс. К. : Видавничий дім "Києво-Могилянська академія", 2011. - 591 с.

4. Северино Е. Сутність нігілізму / Е. Северино. - К. : Темпора, 2020. - 688 с.

5. Талер Р. Новая поведенческая экономика. Почему люди нарушают правила традиционной экономики и как на этом заработать / Р. Талер. Минск : Добрая книга, 2016. - 352 с.

6. Тоффлер Е. Нова парадигма влади. Знання, багатство, сила / Е. Тоффлер. - К. : Акта, 2003. $560 \mathrm{c}$.

7. Уэрта де Сото Х. Социально-экономическая теория динамической эффективности / Х. Уэрта де Сото; [пер. с англ.]. - Челябинск : Социум, 2011. $409 \mathrm{c}$.

8. Шумпетер Й. А. Теорія економічного розвитку: Дослідження прибутків, капіталу, кредиту, відсотка та економічного циклу / Й. А. Шумпетер. - К. : Видавничий дім “КиєвоМогилянська академія”, 2011. - 242 с.

\section{REFERENCES}

1. Zhylin, D. M. (2006), Teorija system: opyt postrojenija kursa, KomKniga, Moscov, 184 s.

2. Kastel`s, M. (2007), Internet-galaktika. Mirkuvannia shchodo Internety, biznesu i suspil`stva, "Vydavnytstvo "Vakler", Kyiv, 304 s.

3. Rojers, E. (2011), Dyfuzija innovatsiy, "Wydavnychiy dim "Kyivo-Mohylianska akademiya", Kyiv, $591 \mathrm{~s}$.

4. Severyno, E. (2020), Sutnist` nigilizmu, Tempora, Kyiv, $688 \mathrm{~s}$.

5. Taler, R. (2016), Novaja povedencheskaja ekonomika. Pochemu liudiy narushajut pravila traditsionnoj ekonomiki i kak na etom zarabotat', Dobraja kniga, Minsk, 352 s.

6. Toffler, E. (2003), Nova paradyhma vlady. Znannia, bahatstvo, syla, Akta, Kyiv, 560 s.

7. Uerta de Soto, C. (2011), Sotsyal`noekonomicheskaja teorija dynamicheskoy effektivnosti, Sotsium, Cheliabinsk, 409 s.

8. Shumpeter, J. A. (2011), Teoriia ekonomichnoho rozvytku: Doslidzhennia prybutkiv, kapitalu, kredytu, vidsotka ta ekonomichnoho tsyklu, Vydavnychyj dim "Kyievo-Mohylians'ka akademiia", K., 242 s.

Стаття надійшла до редакйї 06 грудня $2020 \mathrm{p}$. 